\title{
Monocrotophos in Gandaman village: India school lunch deaths and need for improved toxicity testing
}

\author{
Karl-Heinz Krause $\cdot$ Christoph van Thriel $\cdot$ \\ Paul A. De Sousa $\cdot$ Marcel Leist $\cdot$ Jan G. Hengstler
}

Received: 30 July 2013 / Accepted: 1 August 2013 / Published online: 13 August 2013

(C) Springer-Verlag Berlin Heidelberg 2013

At first glance, recent headlines of "Monocrotophos in Gandaman village" sounded like the title of a Bollywood film featuring a Greek god visiting an Indian village. But, this story had no colorful settings, dancing, or happy ending. And if a Greek god had been involved, his name would have been Thanatos, the personification of death. On July 16, 2013, children in Gandaman village in Bihar, one of the poorest states of India, fell violently sick after eating a school lunch. Twenty-three died, many within a few hours of eating.

Poisoning through environmental chemicals has afflicted humans for a long time. The oldest case of environmental toxicity is scientifically attested by hair analysis of the Tyrolean Neolithic mummy "Ötzi," who died between 3359 and 3105 BC (Bolt 2012). Ötzi suffered from chronic arsenic exposure, probably because of his long-term involvement in copper working. Lead poisoning was prevalent in ancient Rome, and the English idiom "mad as a hatter" is a reminder of workplace exposure to mercury compounds

\section{K.-H. Krause $(\square)$}

Department of Pathology and Immunology, Geneva Medical Faculty, Centre Medical Universitaire, University of Geneva (UNIGE), 1, rue Michel-Servet, 1211 Geneva 4, Switzerland e-mail: Karl-Heinz.Krause@ unige.ch

C. van Thriel · J. G. Hengstler

Leibniz Research Centre for Working Environment and Human Factors (IfADo), Technical University of Dortmund, 44139 Dortmund, Germany

P. A. De Sousa

Scottish Centre for Regenerative Medicine, University of Edinburgh, Edinburgh EH16 4SB, UK

M. Leist

Department of Biology, University of Konstanz (UKN), 78457 Constance, Germany in nineteenth century Britain. The twentieth century was a witness to major environmental poisoning tragedies. Release of industrial waste into Minamata Bay led to high contamination of seafood with mercury compounds, causing a syndrome now called Minamata disease, which led to thousands of deaths and ten thousands of severe cases of methyl mercury neurotoxicity in adults and newborn children in Japan. The Bhopal disaster in India was due to the release of methyl isocyanate from a pesticide plant, and Times Beach, Missouri, has been a ghost town since 1983 because industrial waste oil was used to decrease the dustiness of roads, leading to massive environmental dioxin contamination.

The following picture of events in Gandaman village is now emerging. The children most likely died from an acute cholinergic syndrome due to intoxication with the pesticide monocrotophos. The source of contamination is still unclear, but forensic analysis reported high levels of monocrotophos in the cooking oil used for preparing the school lunches, and a container previously used to store pesticides was found in the kitchen area. According to press reports, the school cook had complained about the color and the smell of the newly delivered cooking oil, but the school principle negated the problem. It appears that the cooking oil was bought from a store owned by the husband of the school principal.

Monocrotophos, dimethyl 2-methylcarbamoyl-1-methyl-vinyl phosphate, is a chemical belonging to the group of organophosphates. Many organophosphates are acetylcholine esterase inhibitors and cause an acute cholinergic syndrome through increased concentrations of the excitatory neurotransmitter acetylcholine in synapses and neuromuscular junctions (thus acting much like chemical weapons such as soman, VX, and sarin). Monocrotophos is insecticidal (including bees!), but also highly toxic to 
other animals, including birds and mammals. Its use has been banned from the United States and subsequently from many Western countries, but it is still widely used in South America, as well as some African and Asian countries including India.

To put things into context, India has a population of over 1.2 billion and is still growing. UNICEF states: "Malnutrition is more common in India than in Sub-Saharan Africa. One in every three malnourished children in the world lives in India" (UNICEF Web site). According to a recent World Bank report (India: Malnutrition Report), about half of child deaths in India are attributable to malnutrition. This would suggest that, in India, the number of children dying from the impact of malnutrition might be in the range of 1 million per year. Obviously, these numbers dwarf the "Gandaman disaster". Together with the apparently very high efficacy of crop protection by monocrotophos, this explains why India continues to use this dangerous pesticide despite warning from the World Health Organization not to do so (Reuters 2013/07/25). In a nutshell, India desperately needs food and its poor heavily depend on affordable mass production, which relies on cheap pesticides. Thus, despite their potential dangers, cheap pesticides will continue to be heavily used for the foreseeable future in India and other impoverished parts of the world. And when combined with factors such as human mistakes, lack of education on handling and dangers, profit maximization in agricultural production, and corrupt practices, this culminates in tragedy. Preventing future "Gandaman disasters" necessitates addressing the root causes of poverty and corruption. However, until these challenges are overcome, toxicologists will have difficult, unrewarding, but important task: accompanying the population of low- and middle-income countries through some more dark decades.

So, what will this involve? Without doubt (and without surprise), developing an improved understanding of the impact of pesticides on human health will be essential. How will a better understanding of pesticide toxicity help people potentially exposed to these compounds? Let us take the example of the "Gandaman disaster." Shortly after the incident, a superintendent of the Medical College Hospital in Patna (a city close to Gandaman) claimed that children who got exposed to, but survived, the acute poisoning will have no "remnant effects on them. The effects of poisoning will be washed after a certain period of time from the tissues" (Huffington Post 2013/07/18). To give him the benefit of doubt, the superintendent might have made this misleading statement to avoid further panic in the local population. Yet, one should worry that such statements will deprive victims of compensation and medical care for long-term consequences of organophosphate poisoning. Such long-term toxicity includes organophosphateinduced delayed polyneuropathy (Richardson et al. 2013) and chronic organophosphate-induced neuropsychiatric disorder (Jokanovic and Kosanovic 2010). It is important to consider that long-term toxicity of organophosphates may occur in the absence of a documented acute intoxication and that such cases might be much more frequent than the fatal acute intoxications, whose tragedy attracts most attention. To make things more complicated, those exposed without showing signs of acute intoxication might be very sensitive to long-term neurotoxic effects (London et al. 2012). Moreover, low-level prenatal exposure to the organophosphate pesticide chlorpyrifos is associated with reduced IQ scores and deficits in working memory, as shown in a longitudinal birth cohort study in New York City (Rauh et al. 2011). Long-term toxicity of organophosphates is particularly well documented for exposure to tricresyl phosphate (Weiner and Jortner 1999) and leptophos (Jokanovic and Kosanovic 2010). To the best of our present medical knowledge, monocrotophos is not devoid of this long-term organophosphate toxicity, but reports are more sketchy (e.g., Singh et al. 2004). Note also that animal testing is not a reliable predictor for the risk of this type of toxicity in humans, as shown, for example, for organophosphate-related carbamate compounds (Richardson et al. 2013). Thus, when it comes to protect the legal rights of victims and their families, our present medical knowledge in this field is not good enough. Toxicity mechanisms need to be demonstrated, and unequivocal cause/consequence chains need to be established.

Understanding the mechanisms of organophosphate toxicity is critical in two respects. First, therapeutic strategies for patients exposed to these toxics can be developed. Obviously, eliminating highly toxic pesticides is preferable to finding therapies for intoxications, but in a real-world scenario, availability of countermeasures can be of immediate benefit to those affected (Lein et al. 2012). Second, such studies and the resulting knowledge on toxicity ranking of compounds should allow legislators to create legal frameworks that encourage the use of pesticides with the least unfavorable toxicology profile. This approach has led to the substitution of several organophosphates by other types of pesticides (e.g., pyrethroids) in Western industrialized countries, and also there, it requires continued toxicological work to understand new health hazards arising from such compounds. Admittedly, this is a "lesser evil" type of approach, yet it may lead to a substantial protection of the concerned populations.

From a chemical point of view, it is very likely that the human toxicity of organophosphates is much less uniform than generally assumed. Figure 1 shows the structure of six selected organophosphates, including monocrotophos, as well as other compounds discussed above. It is plausible that compounds with such a degree of chemical diversity affect different types of targets. Although all of 


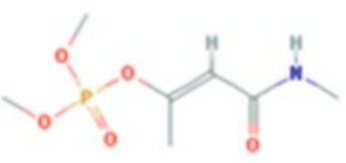

monocrotophos

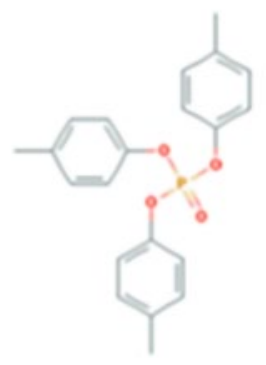

tricresyl phosphate

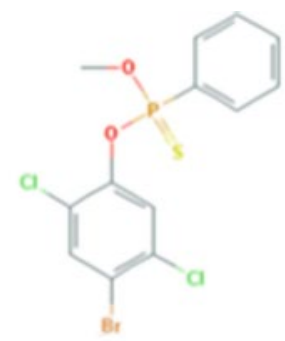

leptophos

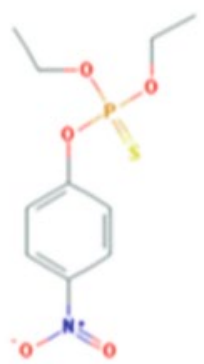

parathion

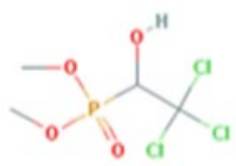

trichlorfon

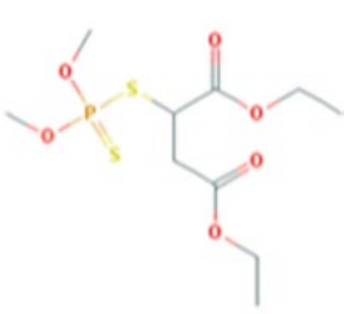

malathion
Fig. 1 Structure of monocrotophos and five other selected organophosphates. All compounds are acetylcholine esterase inhibitors. However, other toxicity targets of these compounds are likely to be compound-specific and have not been studied in-depth. Longterm toxicity has been particularly well documented for leptophos (chronic organophosphate-induced neuropsychiatric disorder) and

them can bind to acetylcholine esterase at nerve terminals, each of them might have different additional targets and target organs. For instance, only a subgroup affects neuropathy target esterase and causes delayed neuropathy (Emerick et al. 2012; Ehrich et al. 1997). Some organophosphates may be involved in inflammation or inflammatory diseases such as asthma (Proskocil et al. 2013; Banks and Lein 2012). Neurodegeneration and spermatotoxicity may be additional side effects ( $\mathrm{Li}$ et al. 2012; Chen et al. 2012).

Thus, it is crucial to identify low-cost pesticides with as little long-term toxicity as possible. To achieve this goal, a close collaboration between clinical, epidemiological, and experimental toxicologists is necessary. Experimentalists modeling the impact of toxic compounds on humans face two challenges that at first glance seem incompatible. Model systems should be physiologically relevant and by necessity human in order to overcome previously encountered limitations in findings drawn from immortalized cell lines and animal models. While there is no deus ex machina to solve all these challenges for the experimental toxicologist, the advent of pluripotent stem cells (PSCs) provides significant improvements (Baquié et al. 2012; Leist et al. 2008), enabling the impact of potentially toxic pesticides to be studied on virtually all types of cells without recourse to immortalized cell lines. Within the last 5 years, tricresyl phosphate (organophosphate-induced delayed polyneuropathy), but has also been described with other organophosphates, including monocrotophos. Parathion (E605) has been associated with risk for cancer. Structures are shown as available from PubChem (http://pubchem.ncbi.nlm.nih.gov/)

the European ESNATS consortium has been developing pluripotent stem cell-based toxicity tests, and first results demonstrate that such test systems may indeed become powerful tools (Krug et al. 2013; Bolt 2013; Vojnits et al. 2012; Kern et al. 2013; Meganathan et al. 2012; Kuegler et al. 2010; Zimmer et al. 2011a, b; Balmer et al. 2012). The consortium has shown that complex functional endpoints can be transferred to in vitro test systems (van Thriel et al. 2012; Kadereit et al. 2012; Zimmer et al. 2012). The availability of both murine and human stem cells even allows species comparisons in vitro and puts species extrapolations from available rodent data to humans on a rational basis (Bal-Price et al. 2012). Thanks to induced PSC technology (Takahashi and Yamanaka 2006), the ethnic diversity of humans can be included into the analysis through a careful selection of PSC lines (Fakunle and Loring 2012). Three-dimensional culture techniques (Hoelting et al. 2013) have enabled the generation of PSC-derived organoids (e.g., Preynat-Seauve et al. 2009), allowing putative toxic compounds to be tested on tissues rather than on isolated cells. Finally, the use of PSCs to generate mice with humanized organs (e.g., Takebe et al. 2013) provides new opportunities to represent physiological complexity. Collectively, we believe these constitute next-generation toxicity platforms. Such platforms will benefit the existing standards of industrial practice, regulatory oversight, and 
medical care in the face of challenges to humans and the environment, such as are all too common in impoverished and in developed parts of the world.

Acknowledgments The authors would like to acknowledge support through the FP7-funded ESNATS program.

\section{References}

Balmer NV, Weng MK, Zimmer B, Ivanova VN, Chambers SM, Nikolaeva E, Jagtap S, Sachinidis A, Hescheler J, Waldmann T, Leist M (2012) Epigenetic changes and disturbed neural development in a human embryonic stem cell-based model relating to the fetal valproate syndrome. Hum Mol Genet 21:4104-4114

Bal-Price AK, Coecke S, Costa L, Crofton KM, Fritsche E, Goldberg A, Grandjean P, Lein PJ, Li A, Lucchini R, Mundy WR, Padilla S, Persico AM, Seiler AE, Kreysa J (2012) Advancing the science of developmental neurotoxicity (DNT): testing for better safety evaluation. ALTEX 29:202-215

Banks CN, Lein PJ (2012) A review of experimental evidence linking neurotoxic organophosphorus compounds and inflammation. Neurotoxicology 33:575-584

Baquié M, Charvet I, Stoppini L, Krause KH (2012) Role of pluripotent stem cells in neurotoxicology testing: impacts and applied innovations. Eur Pharm Rev 17:52-56

Bolt HM (2012) Arsenic: an ancient toxicant of continuous public health impact, from Iceman Ötzi until now. Arch Toxicol $86: 825-830$

Bolt HM (2013) Developmental neurotoxicity testing with human embryonic stem cell-derived in vitro systems: the novel FP7 ESNATS tests are available. Arch Toxicol 87:5-6

Chen JX, Xu LL, Mei JH, Yu XB, Kuang HB, Liu HY, Wu YJ, Wang JL (2012) Involvement of neuropathy target esterase in tri-orthocresyl phosphate-induced testicular spermatogenesis failure and growth inhibition of spermatogonial stem cells in mice. Toxicol Lett 211:54-61

bdnews24. http://bdnews24.com/health/2013/07/23/india-neglects-whowarnings-on-monocrotophos

Ehrich M, Correll L, Veronesi B (1997) Acetylcholinesterase and neuropathy target esterase inhibitions in neuroblastoma cells to distinguish organophosphorus compounds causing acute and delayed neurotoxicity. Fundam Appl Toxicol 38:55-63

Emerick GL, DeOliveira GH, dos Santos AC, Ehrich M (2012) Mechanisms for consideration for intervention in the development of organophosphorus-induced delayed neuropathy. Chem Biol Interact 199:177-184

Fakunle ES, Loring JF (2012) Ethnically diverse pluripotent stem cells for drug development. Trends Mol Med 18:709-716

Hoelting L, Scheinhardt B, Bondarenko O, Schildknecht S, Kapitza M, Tanavde V, Tan B, Lee QY, Mecking S, Leist M, Kadereit S (2013) A 3-dimensional human embryonic stem cell (hESC)derived model to detect developmental neurotoxicity of nanoparticles. Arch Toxicol 87:721-733

Huffington Post (2013/07/18). http://www.huffingtonpost.com/2013/0 7/18/india-school-lunch-deaths_n_3615274.html

Jokanović M, Kosanović M (2010) Neurotoxic effects in patients poisoned with organophosphorus pesticides. Environ Toxicol Pharmacol 29:195-201

Kadereit S, Zimmer B, van Thriel C, Hengstler JG, Leist M (2012) Compound selection for in vitro modeling of developmental neurotoxicity. Front Biosci 17:2442-2460

Kern I, Xu R, Julien S, Suter DM, Preynat-Seauve O, Baquié M, Poncet A, Combescure C, Stoppini L, Thriel CV, Krause KH (2013)
Embryonic stem cell-based screen for small molecules: cluster analysis reveals four response patterns in developing neural cells. Curr Med Chem 20:710-723

Krug AK, Kolde R, Gaspar JA, Rempel E, Balmer NV, Meganathan K, Vojnits K, Baquié M, Waldmann T, Ensenat-Waser R, Jagtap S, Evans RM, Julien S, Peterson H, Zagoura D, Kadereit S, Gerhard D, Sotiriadou I, Heke M, Natarajan K, Henry M, Winkler J, Marchan R, Stoppini L, Bosgra S, Westerhout J, Verwei M, Vilo J, Kortenkamp A, Hescheler J, Hothorn L, Bremer S, van Thriel C, Krause KH, Hengstler JG, Rahnenführer J, Leist M, Sachinidis A (2013) Human embryonic stem cell-derived test systems for developmental neurotoxicity: a transcriptomics approach. Arch Toxicol 87:123-143

Kuegler PB, Zimmer B, Waldmann T, Baudis B, Ilmjärv S, Hescheler J, Gaughwin P, Brundin P, Mundy W, Bal-Price AK, Schrattenholz A, Krause KH, van Thriel C, Rao MS, Kadereit S, Leist M (2010) Markers of murine embryonic and neural stem cells, neurons and astrocytes: reference points for developmental neurotoxicity testing. ALTEX 27:17-42

Lein PJ, Bonner MR, Farahat FM, Olson JR, Rohlman DS, Fenske RA, Lattal KM, Lasarev MR, Galvin K, Farahat TM, Anger WK (2012) Experimental strategy for translational studies of organophosphorus pesticide neurotoxicity based on real-world occupational exposures to chlorpyrifos. Neurotoxicology 33:660-668

Leist M, Bremer S, Brundin P, Hescheler J, Kirkeby A, Krause KH, Poerzgen P, Puceat M, Schmidt M, Schrattenholz A, Zak NB, Hentze $H$ (2008) The biological and ethical basis of the use of human embryonic stem cells for in vitro test systems or cell therapy. ALTEX 25:163-190

Li Y, Lein PJ, Liu C, Bruun DA, Giulivi C, Ford GD, Tewolde T, Ross-Inta C, Ford BD (2012) Neuregulin-1 is neuroprotective in a rat model of organophosphate-induced delayed neuronal injury. Toxicol Appl Pharmacol 262:194-204

London L, Beseler C, Bouchard MF, Bellinger DC, Colosio C, Grandjean P, Harari R, Kootbodien T, Kromhout H, Little F, Meijster T, Moretto A, Rohlman DS, Stallones L (2012) Neurobehavioral and neurodevelopmental effects of pesticide exposures. Neurotoxicology 33:887-896

Meganathan K, Jagtap S, Wagh V, Winkler J, Gaspar JA, Hildebrand D, Trusch M, Lehmann K, Hescheler J, Schlüter H, Sachinidis A (2012) Identification of thalidomide-specific transcriptomics and proteomics signatures during differentiation of human embryonic stem cells. PLoS One 7:e44228

UNICEF. http://www.unicef.org/india/children_2356.htm

Preynat-Seauve O, Suter DM, Tirefort D, Turchi L, Virolle T, Chneiweiss H, Foti M, Lobrinus JA, Stoppini L, Feki A, Dubois-Dauphin M, Krause KH (2009) Development of human nervous tissue upon differentiation of embryonic stem cells in three-dimensional culture. Stem Cells 27:509-520

Proskocil BJ, Bruun DA, Jacoby DB, van Rooijen N, Lein PJ, Fryer AD (2013) Macrophage TNF- $\alpha$ mediates parathion-induced airway hyperreactivity in guinea pigs. Am J Physiol Lung Cell Mol Physiol 304:L519-L529

Rauh V, Arunajadai S, Horton M, Perera F, Hoepner L, Barr DB, Whyatt R (2011) Seven-year neurodevelopmental scores and prenatal exposure to chlorpyrifos, a common agricultural pesticide. Environ Health Perspect 119:1196-1201

Richardson RJ, Hein ND, Wijeyesakere SJ, Fink JK, Makhaeva GF (2013) Neuropathy target esterase (NTE): overview and future. Chem Biol Interact 203:238-244

Singh S, Ranjit A, Parthasarathy S, Sharma N, Bambery P (2004) Organo-phosphate induced delayed neuropathy: report of two cases. Neurol India 52:525-526

Takahashi K, Yamanaka S (2006) Induction of pluripotent stem cells from mouse embryonic and adult fibroblast cultures by defined factors. Cell 126:663-676 
Takebe T, Sekine K, Enomura M, Koike H, Kimura M, Ogaeri T, Zhang RR, Ueno Y, Zheng YW, Koike N, Aoyama S, Adachi Y, Taniguchi H (2013) Vascularized and functional human liver from an iPSC-derived organ bud transplant. Nature 499(7459):481-484

van Thriel C, Westerink RH, Beste C, Bale AS, Lein PJ, Leist M (2012) Translating neurobehavioural endpoints of developmental neurotoxicity tests into in vitro assays and readouts. Neurotoxicology 33:911-924

Vojnits K, Ensenat-Waser R, Gaspar JA, Meganathan K, Jagtap S, Hescheler J, Sachinidis A, Bremer-Hoffmann S (2012) A transcriptomics study to elucidate the toxicological mechanism of methylmercury chloride in a human stem cell based in vitro test. Curr Med Chem 19:6224-6232

Weiner ML, Jortner BS (1999) Organophosphate-induced delayed neurotoxicity of triarylphosphates. Neurotoxicology 20:653-673

World Bank, India malnutrition report. http://web.worldbank.org/ WBSITE/EXTERNAL/COUNTRIES/SOUTHASIAEXT/0, conte
ntMDK:20916955 pagePK:146736 piPK:146830 theSitePK:22 3547,00.html

Zimmer B, Kuegler PB, Baudis B, Genewsky A, Tanavde V, Koh W, Tan B, Waldmann T, Kadereit S, Leist M (2011a) Coordinated waves of gene expression during neuronal differentiation of embryonic stem cells as basis for novel approaches to developmental neurotoxicity testing. Cell Death Differ 18:383-395

Zimmer B, Schildknecht S, Kuegler PB, Tanavde V, Kadereit S, Leist M (2011b) Sensitivity of dopaminergic neuron differentiation from stem cells to chronic low-dose methylmercury exposure. Toxicol Sci 121:357-367

Zimmer B, Lee G, Balmer NV, Meganathan K, Sachinidis A, Studer L, Leist M (2012) Evaluation of developmental toxicants and signaling pathways in a functional test based on the migration of human neural crest cells. Environ Health Perspect 120:1116-1122 